\title{
NEW HOPE FOR THE CRIMINAL JUSTICE REVIEW? A COMMENTARY ON THE IMPLEMENTATION PROCESS
}

\author{
Clare Fox, Researcher, Committee on the Administration of Justice \\ INTRODUCTION
}

The effects of the conflict in Northern Ireland and the subsequent exercise of emergency laws and powers by the British Government contributed, over the years, to declining levels of public confidence in the independence, impartiality and fairness of the criminal justice system. The need to reform the administration of criminal justice was therefore addressed by many of Northern Ireland's political parties and both the British and Irish Governments in the Good Friday Agreement of 1998. Accordingly, the Agreement provided, inter alia, for:

". . . a wide-ranging review of criminal justice (other than policing and those aspects of the system relating to the emergency legislation) to be carried out by the British Government through a mechanism with an independent element, in consultation with the political parties and others." 1

This led to the creation of the Criminal Justice Review; a body composed of senior British Government representatives and independent assessors. However, the capacity of the Review to propose wide-ranging reforms to the criminal justice system was, to an extent, undermined by the fundamentally limiting terms of reference it was afforded under the Agreement. ${ }^{2}$ These terms conferred lead authority for the review process to the British Government, (thus compromising the degree of independence of the Review) and precluded an examination of the use of emergency laws and powers in Northern Ireland. In view of the damage to public confidence resulting from the use of emergency laws, this was a serious omission.

Within the parameters described, the Review nonetheless produced a report, in March 2000, of 294 recommendations for reform to the criminal justice system. $^{3}$ This received the broad support of the communities in Northern Ireland and included a number of significant and far-reaching recommendations for reform, such as: new procedures for all judicial appointments, including the establishment of a Judicial Appointments Commission for Northern Ireland; the creation of a new, independent Public Prosecution Service for Northern Ireland; measures to promote a representative workforce in all parts of the criminal justice system; proposals aimed at placing human rights at the centre of all criminal justice service policies; and reform to aspects of youth justice. In accordance with its terms of reference and the conditional pledge by the British Government to devolve

\footnotetext{
* I am most grateful to Mr Paul Mageean and Professor John Jackson for their helpful comments on drafts of this article.

1 Belfast Agreement, Policing and Justice, para 5.

2 Ibid, Annex B, Review of the Criminal Justice System, p 24.

3 Review of the Criminal Justice System in Northern Ireland (March 2000).
} 
justice and policing powers to Northern Ireland, ${ }^{4}$ the Review also made a number of recommendations which dealt with structures and arrangements post devolution of justice powers. Aside from the political motivations for devolution, which are beyond the scope of this article, it was generally felt that there would be greater government accountability in the area of justice and policing if these functions were administered locally.

The aim of this paper is not to offer a critique of the recommendations of the Criminal Justice Review but to consider the extent to which those recommendations have been implemented since their publication nearly four years ago. This will involve an evaluation of the main implementing measures: the Government Implementation Plan of November 2001; the Justice (Northern Ireland) Act 2002; the Updated Government Implementation Plan of June 2003; and the new Justice (Northern Ireland) Bill 2003, which at the time of writing, had just been published and received its first reading before the House of Lords. ${ }^{5}$

\section{Criminal Justice Review Implementation Plan}

In November 2001, one and a half years after the Report of the Criminal Justice Review, the Government made public its response in the Criminal Justice Review Implementation Plan. The Government accepted fully the majority of the Review recommendations, rejected only one, ${ }^{6}$ and as to the remainder, accepted them "in principle", "with qualifications" or subject to "further consideration". The main problem with the Plan however was that it did not stipulate the measures that needed to be taken by the various criminal justice agencies to give effect to those recommendations of the Review which the Government had accepted, nor did it impose strict target dates for full implementation of the recommendations. In this sense, the document failed to deliver the key elements of a "plan", suggesting an underlying lack of political and institutional engagement in the review process.

The Plan referred in many instances to the need for legislation in order to implement a large number of the Review recommendations. To coincide with the publication of the Implementation Plan therefore, the Government published a draft Justice (Northern Ireland) Bill. This raised the expectation that once the Bill became law, the way would be clear for full implementation of the Review.

\section{Justice (Northern Ireland) Act 2002}

In July 2002, the Justice Bill received Royal Assent and became the Justice (Northern Ireland) Act 2002. The Act made provision for many of the Review recommendations, including those relating to: the new procedures for judicial appointments, ${ }^{7}$ including the creation of the Judicial Appointments Commission; ${ }^{8}$ the new Prosecution Service for Northern

4 Belfast Agreement, para 7.

5 The Justice (NI) Bill was first published on $4^{\text {th }}$ December 2003.

6 Recommendation 46 on making it an offence to interfere with the Prosecutor.

7 Justice (NI) Act 2002, s 4.

8 Ibid, s 3. 
Ireland; 9 the creation of the new offices of Attorney General for Northern Ireland ${ }^{10}$ Advocate General, ${ }^{11}$ Chief Inspector for Criminal Justice ${ }^{12}$ and Lay Magistrate ${ }^{13}$ reform of the youth justice system; ${ }^{14}$ and new regulations on the use of courtroom symbols, flags and oaths of allegiance. ${ }^{15}$

However the content of the Bill had been hotly contested as it passed through Parliament and a number of recommendations which had not received the full support of the Government in the Implementation Plan, were omitted from the Act. This may be seen as the first shortcoming of the Act, in terms of its capacity to give full effect to the Review.

An example of an important recommendation which was affected in this way, was recommendation 4. This placed a requirement on "whatever machinery is devised for administering criminal justice matters after devolution" to develop a strategy for securing a workforce, across the criminal justice system, which is reflective of the community in Northern Ireland. The fact that this recommendation appears (although this is disputed by members of the Review) to place the reform solely in the context of devolution, should not have affected its inclusion in the Justice Act. Many of the provisions in the Act, as will be discussed below, were drafted on the contingency of the devolution of justice powers to Northern Ireland and these will not enter into force until that time. It is suggested instead that the reason why this recommendation was not placed on a statutory footing, was due to a degree of institutional resistance to tackling the difficult area of representation. Indeed, the fact that the Government only accepted the Review recommendation "in principle" indicates that implementation will most likely be difficult.

A second problem in terms of the substance of the Justice Act was that a number of Review recommendations, to which the Act purported to give effect, were in fact diluted or significantly altered in character during the drafting process. The most publicised example of this was the express extension of recommendation 141 on the display of symbols inside and outside of courthouses. Under political pressure, the then Secretary of State, Dr. John Reid, citing reasons of "architectural or historical merit", ${ }^{16}$ tabled an amendment at the drafting stages of the Justice Bill so as to exempt a number of courts from the recommendations of the Review on the display of symbols inside certain designated courthouses. ${ }^{17}$ Moreover, the Secretary of State, in a complete departure from the original Review, also interpreted recommendation 141 to mean that new courthouses should be able to display coats of arms. This had the effect of allowing the new Laganside

9 Ibid, s 29(1).

10 Ibid, s 22(1).

11 Ibid, s 27.

12 Ibid, $\mathrm{s} 45$

13 Ibid, s 9.

14 Ibid, part IV, ss 53-65.

15 Ibid, part V, ss 66-67.

16 NIO Press Release, $1^{\text {st }}$ March 2002.

17 The courtrooms affected were in the Royal Courts of Justice in Belfast, the courtrooms in the Armagh, Banbridge, Magherafelt and Omagh Courthouses and Court No 1 in the Courthouse in Downpatrick. The amendment came into effect as s 66(2) of the Justice Act. 
Courthouse, which was subsequently opened in February 2003, to bear the Royal Coat of Arms.

Other, less publicised examples of where the Justice Act diluted the scope and effect of certain Review recommendations were: recommendation 21 on the duty of the Director of Public Prosecutions to refer all instances of police malpractice to the Ombudsman; ${ }^{18}$ and recommendation 75 , which provided that the Prime Minister must make senior judicial appointments on the basis of recommendations of the First and Deputy First Minister. ${ }^{19}$ These two sections of the Act are however subject to amendment in the new Justice Bill, the detail of which will be discussed later.

However the larger issue preventing the Justice Act from giving effect to the Review, has been the significant delay to the commencement of most of its provisions. The reality is that the vast majority of the Act has not yet entered into force, despite publication over a year and a half ago. The sections of the Act which have been commenced to date are, for the most part, rather minor, such as the provisions relating to court security, ${ }^{20}$ judicial pensions, ${ }^{21}$ criteria for lay magistrates ${ }^{22}$ and inconsequential amendments. ${ }^{23}$ One important exception to this has been the commencement of section 45 , together with schedule 8, on the new office of the Chief Inspector for Criminal Justice. This new office has been taken up by Mr. Kit Chivers, formerly HM Chief Inspector of Magistrates' Courts Service, and it will hopefully play a positive role in ensuring the efficiency of the criminal justice system in Northern Ireland and in evaluating the impact of the new reforms.

A lack of sufficient political and institutional will to engage in the process of criminal justice reform is the main reason for the poor and half-hearted implementation of the Justice Act and Review in general. There is however also another explanation for the source of delay in implementing a small number of the Act's provisions. These are the provisions which, for constitutional reasons, require the devolution of justice functions to Northern Ireland before they can be fully operational as envisaged by the Act. Such provisions, while very important, account for only a small percentage of the total of the Act and include the sections which relate to: the recommendations for appointment of members of the judiciary by the First and Deputy First Ministers, ${ }^{24}$ the functioning of the proposed new offices of Attorney General for Northern Ireland ${ }^{25}$ and Advocate General; ${ }^{26}$ the appointment of the Director of the Public Prosecution Service by a local minister; ${ }^{27}$ the new role of the Lord Chief Justice as head of the judiciary in Northern Ireland; ${ }^{28}$ the abolition of the Northern Ireland Court Service, ${ }^{29}$ and

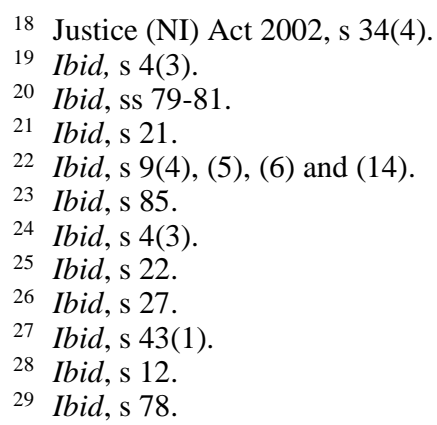


other structural arrangements post devolution of justice functions. There is no certainty as to when these sections of the Act will come into effect, given the distant prospect of the devolution of justice and policing powers to Northern Ireland. Any consequent interference to the reform process, however, should be kept to a minimum and all possible interim and preparatory measures should be taken.

In summary, therefore, it is fair to say that the Justice Act has to date provided little or no impetus to the implementation process. It is merely an enabling piece of legislation, whose terms will be brought into force when the British Government, in consultation with the criminal justice agencies, so wishes.

\section{Joint Declaration of the British and Irish Governments}

In view of the overriding need for political and institutional will in order to advance implementation of the Review, the strong statements of support for the Criminal Justice Review, in the Joint Declaration of the British and Irish Governments of $19^{\text {th }}$ April 2003, offer much encouragement. The Joint Declaration set out a programme, devised by both Governments, for implementing the outstanding elements of the Good Friday Agreement. In relation to the Criminal Justice Review, the Declaration announced the Government's intention to appoint an independent Oversight Commissioner to provide independent scrutiny of the Government's decisions on the Review. This was a significant development, as up to this point the British Government had strongly resisted the creation of an Oversight Commissioner despite considerable lobbying. Lord Clyde, the former Scottish Law Lord, was subsequently appointed to the new Office in June 2003.

The Declaration also referred to "major transformational change" that would form the basis of an updated Government implementation strategy and promised the introduction of a second Justice Bill to amend the Justice (Northern Ireland) Act 2002. These measures will now be considered in turn to assess whether they bring new hope for implementation of the Criminal Justice Review.

\section{The Updated Implementation Plan}

The Updated Implementation Plan was published by the Government in June 2003. For the first time in the implementation process, the Updated Plan actually set out, in varying degrees of detail, the actions that both the Government and the respective criminal justice agencies were taking in order to give effect to the Review, and it fixed deadlines for the completion of these activities.

This new information was a particularly helpful indication of the progress that was being made by the Prosecution Service in implementing the many recommendations pertaining to it. The Plan revealed that the Review recommendations would be introduced on a gradual and progressive basis, with the use of a number of pilot projects. These projects, which bring into operation recommendations 17 and 60 on the expansion of the duties of the Prosecution Service and the decentralisation of the Service, were commenced on the $1^{\text {st }}$ December 2003 in South Belfast. Whilst statutory provisions have already been made in the Justice Act to give effect to the 
Review recommendations on the Prosecution Service, these pilots are operating outside of the Act, on the basis of the Prosecution of Offences (Northern Ireland) Order 1972. Similarly, the new codes of practice and ethics for the Prosecution Service, as recommended by the Review, ${ }^{30}$ are expected to be published in draft form in December 2003, but the corresponding sections of the Justice Act ${ }^{31}$ will not be brought into force at this stage, neither does the Plan indicate when this will take place.

From the point of view of enhancing the accountability of the new Prosecution Service, the Review had recommended ${ }^{32}$ that the Service should produce an annual report. However section 39 of the Justice Act, which gives effect to this recommendation, is being interpreted by the Prosecution Service to mean that the first annual report is not due to be published until the completion of all the prosecution reforms, which according to the current schedule is December 2006. This interpretation of the provision is quite alarming and appears almost to take advantage of the long "roll-out" process of the reforms. At the launch of the Prosecution Service in October 2003, there was at least a commitment to publish an independent evaluation of the pilots in July/August 2004 and in the absence of an annual report it is imperative that this commitment is met.

The Plan indicates that it is not only the reforms to the Prosecution Service which have begun without commencement of the Justice Act, but aspects of the Review recommendations in relation to youth justice and community safety partnerships have also begun to operate in the interim on a basis other than the Justice Act. For example, the Youth Justice Agency has now replaced the old Youth Justice Board. In August 2002 a Director was appointed to head the Youth Conference Service and the pilots for youth conferencing have already begun under existing legislation. Similarly, the Review recommendations on community safety partnerships are now partly in operation, having been so authorised by the Government. This is in spite of the fact that the sections on community safety partnerships in the Justice Act have not yet been commenced. ${ }^{33}$ While these are all positive measures towards implementing the Review, it is nonetheless desirable that the relevant sections of the Justice Act are commenced without delay.

\section{Justice (Northern Ireland) Bill 2003}

One of the most important aspects of the Updated Plan, from the point of view of advancing the implementation process, was that it included a commitment from the Government to introduce a new Justice (Northern Ireland) Bill. The purpose of this Bill is to amend those sections of the Justice Act which did not reflect the original Review recommendations and to make statutory provision for other Review recommendations that were not included in the Justice Act.

According to the terms of the Updated Implementation Plan, the Bill would contain the following provisions:

30 Criminal Justice Review, recommendation 50

31 Justice (NI) Act, s 37.

32 Supra, $\mathrm{n} 30$.

33 Justice (NI) Act, part 5, ss 71-72. 
"the Judicial Appointments Commission will be established prior to, as opposed to after, the devolution of criminal justice and policing powers (thus exceeding the terms of the original Review recommendation);

there will be equal limits on the length of service for all members of the Commission (formerly this limit only extended to its lay members);

the Commission as a whole, rather than just its lay members, will be required to be reflective of the community in Northern Ireland;

it will be a key objective of the Commission to engage in a programme of action to secure a reflective judiciary in Northern Ireland, consistent with the principle of merit;

the Prime Minister will appoint the Lord Chief Justice and the Lord Justices of Appeal based on the recommendation of the First Minister and Deputy First Minister (formerly the Prime Minister was merely requested to consult with the First and Deputy First Ministers);

the Lord Chief Justice's consent for the establishment of a tribunal to remove or suspend a member of the judiciary will be removed;

section 34 of the Justice Act in relation to the power of the Director of Public Prosecutions (DPP) to refer instances of police malpractice to the Police Ombudsman will be strengthened to place a duty on the Director to refer all such cases;

a new offence, of seeking to influence the DPP without legitimate cause, will be created;

there will be a duty on the criminal justice agencies to have due regard to relevant international and human rights standards in carrying out their functions."

In light of the many failings associated with the implementation of the Review so far, there was a degree of concern over whether these provisions, as listed in the Plan, would actually be borne out in the drafting stages of the Bill. Unfortunately, however, at the time of writing this article, the Bill was published for the first time and once more defeated expectations. While the published Justice Bill remained true to the Updated Plan in regard to making the necessary arrangements for bringing forward the creation of the Judicial Appointments Commission and the other provisions in respect of the composition and stated objectives of the Judicial Appointments Commission, it did not preserve the nature of the amendments to the Justice Act, as stated in the Updated Plan, on senior judicial appointments, the duty on the DPP to refer instances of police malpractice to the Ombudsman, and the requirement that all criminal justice agencies should have due regard to international human rights standards. In all instances, these areas received much weaker formulations which leaned towards maintaining the status quo rather than introducing even limited reform. 
In regard to the appointment of the Lord Chief Justice and Lord Justices of Appeal, the published Bill has failed to meet the expectation raised in the Updated Plan that the Prime Minister will appoint persons to these positions "based on the recommendations of the First and Deputy First Minister". ${ }^{34}$ Instead the Bill has diminished the role of the First and Deputy First Minister by requiring the Prime Minister only to "consider" any recommendation for appointment made by the First and Deputy First Minister. ${ }^{35}$

Clause 6(3), on the duty of the Director of Public Prosecutions to refer matters of police malpractice to the Ombudsman, also falls short of the Review and of what had been promised in the Updated Plan. The wording of the clause in question, confers an excessive degree of discretion on the Director to decide whether a matter is one which must be referred to the Ombudsman. The degree of subjectivity involved in this assessment could make it very difficult to make the Director accountable through a judicial review challenge.

The third area where the Bill has fallen short of both the Review and the guarantee in the Updated Plan is in relation to the role of international human rights standards in the reform process. The Plan, as shown above, stated that all criminal justice agencies would be under a duty to have due regard to international human rights standards. The Bill, however, proposes a curious and convoluted formulation whereby it will be for the Attorney General for Northern Ireland to issue guidance, as and when he or she thinks fit, to the listed criminal justice agencies, on the exercise of their functions, in light of relevant international standards. This raises doubts over the genuine commitment of the Government to the application of international human rights standards in the criminal justice system in Northern Ireland.

It is also worth commenting that clause $8(8)$ of the Bill exempts the Prosecution Service from having any regard to human rights guidance issued by the Attorney General for Northern Ireland where that guidance would be inconsistent with a code of practice issued under section 37 of the Justice Act. It is difficult to foresee how the new and first ever code of practice for the Prosecution Service would be inconsistent with international human rights standards.

In light of these failings, the hope that the new Bill may make amends for the shortcomings of the Justice Act seems somewhat diminished. However, it is important nonetheless that the Judicial Appointments Commission proceeds in advance of devolution as agreed in the Joint Declaration and there is a chance that the three sections commented on above will be amended during the passage of the Bill. Some of the political parties have already addressed their concerns about the new Bill to Government and the Criminal Justice Oversight Commissioner may, in exercise of his terms of reference, scrutinise the passage of the Bill to ensure that it truly reflects the recommendations of the Criminal Justice Review.

34 Review of the Criminal Justice System in Northern Ireland, recommendation 75.

35 Justice (NI) Bill (4 ${ }^{\text {th }}$ December 2003), clause 4. 
446 Northern Ireland Legal Quarterly [Vol. 54, No. 4]

\section{CONCLUSION}

The title of this article questions whether there is new hope for the implementation of the Review. Having charted, in general terms, the progress of the Review, it is clear that the recent developments of the publication of the Updated Plan, the new Justice Bill and the creation of the Oversight Commissioner have the potential, if properly used, to give new life to the implementation process. Progress is slow, however, and resistance to change continues to impede the full delivery of the reforms. Above all, the success of the Review depends on the political and institutional will to commit to the process of criminal justice reform in a whole hearted manner. 